\title{
Safety of IL-23/17 Antagonists in Patients with Psoriasis or Other Immune-mediated Inflammatory Diseases: A Systematic Meta-Analysis.
}

\section{Siying Li}

Central South University

\section{Suhan Zhang}

Central South University

Guishao Tang

Central South University

\section{Ruifang Wu}

Central South University

Yuwen Su ( $\nabla$ suyuwen1963@csu.edu.cn )

Central South University

\section{Research article}

Keywords: Psoriasis, IMIDs, IL-23/17 axis antagonists, Safety, Nervous System Disorder, Cardiovascular Disorder, Hypertension

Posted Date: August 4th, 2020

DOI: https://doi.org/10.21203/rs.3.rs-49001/v1

License: (1) This work is licensed under a Creative Commons Attribution 4.0 International License. Read Full License 


\section{Abstract}

Background: The IL-23/17 axis plays central role in the pathogenesis of several immune-mediated inflammatory diseases (IMIDs). IL-23/17 antagonists showed significant improvement in the treatment for psoriasis and other IMIDs, including psoriasis(PSO), psoriatic arthritis(PsA), rheumatoid arthritis(RA) and ankylosing spondylitis(AS).

Objective: To assess the safety of IL-23/17 antagonists therapy on patients with psoriasis and other IMIDs.

Methods: Pooled analysis from thirty-nine placebo-controlled randomized clinical trials (RCTs) of IL-23/17 axis antagonists for IMIDs. Incidences of adverse events (AEs), serious adverse events (SAEs) and AEs of interest were applied to evaluate the safety profile.

Result: A Total of 15967 patients were exposed to IL-23/17 axis antagonists. The proportions of patients suffered at least one $A E$ in antagonists group and placebo-control group are $67.5 \%$ and $51.1 \%$ respectively. Incidence of SAE was increased in patients treated with IL-23/17 axis antagonists compared to patients given placebo (relative risk 2.03; 95\% $\mathrm{Cl}, 1.62,2.56)$. Incidence of AEs of interest were all increased in patients treated with IL-23/17 axis antagonists compared to patients given placebo.

Conclusion: In this analysis, we found increased risk of AEs, SAEs, nervous system disorder, cardiovascular disorder and hypertension among patients with IMIDs treated with IL-23/17 axis antagonists.

\section{Introduction}

Psoriasis is an immune-mediated inflammatory, genetic skin disorder, which affects over 2-3\% of the world's population in broad outline[1] [2] [3] [4]. Patients with psoriasis suffer great physical and psychological burden and are unable to get a high quality of life. In clinical practice, a combination of glucocorticosteroids, vitamin D derivatives, phototherapies is common used for mild to moderate psoriasis treatment. Moreover, systemic therapies, such as methotrexate, ciclosporin, fumaric acid esters and biologic drugs are widely applied to moderate to severe psoriasis [5]. In the past decades, with a better understanding of the pathogenesis of psoriasis, biologics targeting to key inflammatory pathways, such as the TNF-a signaling and IL-23/17 axis, are developed and proved effective.

IL-23 drives the production of Th17 cells from naïve T cells and induce the differentiation of Th17 cells that produce several inflammatory cytokines such as IL-17A and IL-17F, which modulate hallmark inflammatory installed by noxious stimulus in immune-mediated inflammatory diseases (IMIDs) [6] [7]. IL-23/17 axis antagonists include IL-23 antagonist, a dimer composed of p40 and p19, and IL-17A antagonists. The efficiency of the latter was improved significantly in treatment for IMIDs, involving psoriasis(PSO), psoriatic arthritis(PSA), rheumatoid arthritis(RA) and ankylosing spondylitis(AS). Ustekinumab, targeting p40 subunit of IL-23, is the first IL-23/17 antagonist to be approved for psoriasis vulgaris after the TNF-a antagonists. In 2015, the first IL-17A antagonists, Secukinumab, was approved for psoriasis treatment[4] [5]. And Ixekizumab was another biological agent targeting to IL-17A. IL-23/17 axis antagonists have been related to potential adverse events(AEs), including hypertension, nervous system disorders, cardiovascular disorder, serious adverse events(SAEs). Nervous system disorders mainly include headache, Carotid artery occlusion, Cerebrovascular accident et.al also been taken into account.

As increased demands of patients for disease remission and quality of life, there are more therapeutic means for IMIDs. As doctors, it is necessary for adequately weigh the risk/benefit ratio of drugs before applying to patients, which including fully understanding the exact safety profile of IL-23/17 axis antagonists. 
In this report, we analyze the potential AEs risk of IL-23/17 axis antagonists based on data from clinical randomized controlled trials. To our knowledge, this is the first safety analysis of three IL-23/17 axis antagonists as regards the four IMIDs. What's more, the risks of hypertension and nervous system disorders in patients with IMIDs receiving IL-23/17 axis antagonists therapy were rarely mentioned before.

\section{Materials And Methods}

\section{Information Sources and Searches}

The following databases were systematically searched: EMBASE, MEDLINE, and Cochrane Central Register of Controlled Trials (CENTRAL) from the beginning to March 2020. Search strategies included the following terms: ['L23/17 axis antagonists' OR ('Ustekinumab' OR 'CNTO 1275') OR ('secukinumab' OR 'Cosentyx' OR 'AIN457') OR ('Ixekizumab' OR 'Taltz')] AND ['psoriasis' OR 'psoriatic arthritis' OR 'rheumatoid arthritis' OR 'ankylosing spondylitis'] AND ['safety' OR 'adverse events' OR 'hypertension' OR 'serious adverse events' OR 'nervous system disorders' OR 'cardiovascular disorder'] AND ['randomized controlled trial'].

\section{Selected Studies and Integrated Data}

Three authors $(A, B, C)$ join the program. Author $A$ searched databases and deleted duplicates by title. The abstracts and full-text articles were screened by author $A, B$ and $C$, and they checked whether the studies conform to the protocol or meet the criteria. If not, the study would be excluded. Common inclusion criteria for these trials included patients aged $\geq 18$ years, placebo-controlled, and ensured that the index disease was present and that patients had active disease appropriate for clinical trial enrolment. Inclusion and exclusion criteria are shown in supplementary table1.

Two authors independently gathered information from each study and another author resolved the differences. Data collected included: NCT number, disease type, year of study, study design, drug name, study duration, number of patients, exposure definition, AEs (hypertension, nervous system disorders, cardiovascular disorder, SAEs).

\section{Data Analysis}

Data was summarized from placebo-controlled randomized clinical trials(RCTs) for meta-analysis, which published on ClinicalTrials.gov or other journals. Incidence rates of AEs, SAEs, hypertension, nervous system disorders and cardiovascular disorder were evaluated by Review Manager (RevMan) software (Version 5.3. Copenhagen: The Nordic Cochrane Centre, The Cochrane Collaboration, 2014). Forest plot are constructed by plotting the risks of SAE, nervous system disorders, cardiovascular disorder and hypertension between antagonists groups and placebo groups. Means of Chi Square and $\mathrm{I}^{2}$ tests were used to evaluate Heterogeneity among studies. According to the Cochrane Handbook for Systematic Reviews of Interventions, it might not be important when $\mathrm{I}^{2}$ is below $40 \%$; the value of $\mathrm{I}^{2}$ between $30-60 \%$ may represent moderate heterogeneity; the value of $\mathrm{I}^{2}$ between $50-90 \%$ may represent substantial heterogeneity; there may be considerable heterogeneity when the value of $\mathrm{I}^{2}$ is between $75-100 \%$. Overall, $\mathrm{I}^{2} \leq 50 \%$ is acceptable[8]. To allow for any heterogeneity among studies, random-effects models were used to give a more conservative estimate of the effect of individual therapies. Relative Risks (RR) and their corresponding 95\% confidence intervals were described. All RCTs were judged risk of bias by random sequence, allocation concealment, blinding of participants and personnel, blinding of outcome assessment, incomplete outcome data and other bias according to the Cochrane criteria guidelines. Grading of suggestions from Recommendations Assessment Development and Evaluation (GRADE) working group, authors determined the quality of evidence for each outcome. 


\section{Results}

Data were derived from 36 global clinical randomized controlled trials of IL-23/17 axis antagonists, 15 in PSO, 11 in PsA, 4 in AS, 6 in RA, until March 2020 (Supplemental Fig. 1) [9] [10] [11 12] [13] [14] [15] [16] [17] [18] [19] [20] [21] [22] [23] [24] [25 26] [27] [28] [29] [30] [31] [32] [33] [34] [35] [36] [37] [38] [39] [40]. A Total of 13368 patients received IL-23/17 axis antagonists, 4833 patients received placebo. Among these, 9415 were patients with PSO, 5222 were patients with PsA, 1466 were patients with AS, 2098 were patients with RA. The main included study characteristics are listed in Table 1. 
Table 1

Main characteristics of included studies.

\begin{tabular}{|c|c|c|c|c|c|c|c|}
\hline Disease & Author & $\begin{array}{l}\text { Patients, } \\
\text { n }\end{array}$ & $\begin{array}{l}\text { Mean } \\
\text { age } \\
, y\end{array}$ & $\begin{array}{l}\text { Female } \\
\%\end{array}$ & Study design & Exposure & $\begin{array}{l}\text { Study } \\
\text { Duratiom }\end{array}$ \\
\hline \multicolumn{8}{|c|}{ Psoriasis } \\
\hline & Paul C 2014 & 182 & 44.7 & 31.3 & $\begin{array}{l}\text { Phase 3, randomized, } \\
\text { parallel assignment, } \\
\text { double-blind, placebo- } \\
\text { controlled study }\end{array}$ & $\begin{array}{l}\text { Placebo; } \\
\text { Secukinumab } \\
150 \text { or } \\
300 \text { mg }\end{array}$ & 12weeks \\
\hline & $\begin{array}{l}\text { Gordon KB } \\
2016\end{array}$ & 1296 & 45.7 & 31.9 & $\begin{array}{l}\text { Phase 3, randomized, } \\
\text { parallel assignment, } \\
\text { double-blind, placebo- } \\
\text { controlled study }\end{array}$ & $\begin{array}{l}\text { Placebo; } \\
\text { lxekizumab } \\
80 \mathrm{mg}\end{array}$ & 12 weeks \\
\hline & $\begin{array}{l}\text { Gordon KB } \\
2016\end{array}$ & 1224 & 45.0 & 32.9 & $\begin{array}{l}\text { Phase 3, randomized, } \\
\text { parallel assignment, } \\
\text { double-blind, placebo- } \\
\text { controlled study }\end{array}$ & $\begin{array}{l}\text { Placebo; } \\
\text { lxekizumab } \\
80 \text { mg }\end{array}$ & 12weeks \\
\hline & $\begin{array}{l}\text { Gordon KB } \\
2016\end{array}$ & 1346 & 45.8 & 31.8 & $\begin{array}{l}\text { Phase 3, randomized, } \\
\text { parallel assignment, } \\
\text { double-blind, placebo- } \\
\text { controlled study }\end{array}$ & $\begin{array}{l}\text { Placebo; } \\
\text { Ixekizumab } \\
80 \text { mg }\end{array}$ & 12 weeks \\
\hline & $\begin{array}{l}\text { Krueger GG } \\
2007\end{array}$ & 320 & 44.9 & 43.1 & $\begin{array}{l}\text { Phase 2, randomized, } \\
\text { parallel assignment, } \\
\text { double-blind, placebo- } \\
\text { controlled study }\end{array}$ & $\begin{array}{l}\text { Placebo; } \\
\text { Ustekinumab } \\
45 \text { or } 90 \text { mg }\end{array}$ & 36 weeks \\
\hline & $\begin{array}{l}\text { Langley RG } \\
2014\end{array}$ & 1306 & 44.4 & 28.9 & $\begin{array}{l}\text { Phase 3, randomized, } \\
\text { parallel assignment, } \\
\text { double-blind, placebo- } \\
\text { controlled study }\end{array}$ & $\begin{array}{l}\text { Placebo; } \\
\text { Secukinumab } \\
150 \text { or } \\
300 \text { mg }\end{array}$ & 52weeks \\
\hline & $\begin{array}{l}\text { Langley RG } \\
2014\end{array}$ & 738 & 45.1 & 31.0 & $\begin{array}{l}\text { Phase 3, randomized, } \\
\text { parallel assignment, } \\
\text { double-blind, placebo- } \\
\text { controlled study }\end{array}$ & $\begin{array}{l}\text { Placebo; } \\
\text { Secukinumab } \\
150 \text { or } \\
300 \text { mg }\end{array}$ & 48weeks \\
\hline & $\begin{array}{l}\text { Leonardi C } \\
2012\end{array}$ & 142 & 46.2 & 43.0 & $\begin{array}{l}\text { Phase 2, randomized, } \\
\text { parallel assignment, } \\
\text { double-blind, placebo- } \\
\text { controlled study }\end{array}$ & $\begin{array}{l}\text { Placebo; } \\
\text { lxekizumab } \\
10,25,75 \text { or } \\
150 \text { mg }\end{array}$ & 20 weeks \\
\hline & $\begin{array}{l}\text { Leonardi CL } \\
2008\end{array}$ & 766 & 45.3 & 30.7 & $\begin{array}{l}\text { Phase 3, randomized, } \\
\text { parallel assignment, } \\
\text { double-blind, placebo- } \\
\text { controlled study }\end{array}$ & $\begin{array}{l}\text { Placebo; } \\
\text { Ustekinumab } \\
45 \text { or } 90 \text { mg }\end{array}$ & 12 weeks \\
\hline & Novartis 2010 & 125 & 45.9 & 27.2 & $\begin{array}{l}\text { Phase 3, randomized, } \\
\text { parallel assignment, } \\
\text { double-blind, placebo- } \\
\text { controlled study }\end{array}$ & $\begin{array}{l}\text { Placebo; } \\
\text { Secukinumab }\end{array}$ & 37 weeks \\
\hline & Novartis 2012 & 177 & 45.9 & 33.9 & $\begin{array}{l}\text { Phase 3, randomized, } \\
\text { parallel assignment, } \\
\text { double-blind, placebo- } \\
\text { controlled study }\end{array}$ & $\begin{array}{l}\text { Placebo; } \\
\text { Secukinumab } \\
150 \text { or } \\
300 \text { mg }\end{array}$ & 12 weeks \\
\hline
\end{tabular}




\begin{tabular}{|c|c|c|c|c|c|c|c|}
\hline Disease & Author & $\begin{array}{l}\text { Patients, } \\
\mathrm{n}\end{array}$ & $\begin{array}{l}\text { Mean } \\
\text { age } \\
, y\end{array}$ & $\begin{array}{l}\text { Female } \\
\%\end{array}$ & Study design & Exposure & $\begin{array}{l}\text { Study } \\
\text { Duratiom }\end{array}$ \\
\hline & Novartis 2015 & 100 & 43.8 & 20.0 & $\begin{array}{l}\text { Phase 3, randomized, } \\
\text { parallel assignment, } \\
\text { double-blind, placebo- } \\
\text { controlled study }\end{array}$ & $\begin{array}{l}\text { Placebo; } \\
\text { Secukinumab }\end{array}$ & 52weeks \\
\hline & Novartis 2017 & 543 & 40.2 & 24.1 & \multicolumn{2}{|c|}{$\begin{array}{l}\text { Phase 3, randomized, } \\
\text { parallel assignment, double-blind, } \\
\text { placebo-controlled study }\end{array}$} & 52weeks \\
\hline & Papp KA 2008 & 1230 & 46.2 & 31.7 & $\begin{array}{l}\text { Phase 3, randomized, } \\
\text { parallel assignment, } \\
\text { double-blind, placebo- } \\
\text { controlled study }\end{array}$ & $\begin{array}{l}\text { Placebo; } \\
\text { Ustekinumab } \\
45 \text { or } 90 \text { mg }\end{array}$ & 12 weeks \\
\hline & Paul C 2015 & 404 & 44.1 & 24.3 & $\begin{array}{l}\text { Phase 2, randomized, } \\
\text { parallel assignment, } \\
\text { double-blind, placebo- } \\
\text { controlled study }\end{array}$ & $\begin{array}{l}\text { Placebo; } \\
\text { Ustekinumab } \\
45 \text { or } 90 \mathrm{mg}\end{array}$ & 12 weeks \\
\hline \multicolumn{8}{|c|}{ Psoriatic Arthritis } \\
\hline & $\begin{array}{l}\text { Genovese MC } \\
2013\end{array}$ & 237 & 54.9 & 77.2 & $\begin{array}{l}\text { Phase 2, randomized, } \\
\text { parallel assignment, } \\
\text { double-blind, placebo- } \\
\text { controlled study }\end{array}$ & $\begin{array}{l}\text { Placebo; } \\
\text { Secukinumab } \\
25,75,150 \text { or } \\
300 \text { mg }\end{array}$ & 20weeks \\
\hline & $\begin{array}{l}\text { Gottlieb A } \\
2009\end{array}$ & 146 & 48.7 & 43.8 & $\begin{array}{l}\text { Phase 2, randomized, } \\
\text { crossover assignment, } \\
\text { double-blind, placebo- } \\
\text { controlled study }\end{array}$ & $\begin{array}{l}\text { Placebo; } \\
\text { Secukinumab } \\
63 \text { mg }\end{array}$ & 12 weeks \\
\hline & $\begin{array}{l}\text { Kavanaugh A } \\
2016\end{array}$ & 312 & 47.9 & 52.6 & $\begin{array}{l}\text { Phase 3, randomized, } \\
\text { parallel assignment, } \\
\text { double-blind, placebo- } \\
\text { controlled study }\end{array}$ & $\begin{array}{l}\text { Placebo; } \\
\text { Ustekinumab } \\
45 \text { or } 90 \mathrm{mg}\end{array}$ & 44weeks \\
\hline & Kivitz AJ 2019 & 341 & 49.0 & 42.2 & $\begin{array}{l}\text { Phase 3, randomized, } \\
\text { parallel assignment, } \\
\text { double-blind, placebo- } \\
\text { controlled study }\end{array}$ & $\begin{array}{l}\text { Placebo; } \\
\text { Secukinumab } \\
150 \mathrm{mg}\end{array}$ & 112 weeks \\
\hline & $\begin{array}{l}\text { Mclnnes IB } \\
2013\end{array}$ & 598 & 47.1 & 46.3 & $\begin{array}{l}\text { Phase 3, randomized, } \\
\text { parallel assignment, } \\
\text { double-blind, placebo- } \\
\text { controlled study }\end{array}$ & $\begin{array}{l}\text { Placebo; } \\
\text { Ustekinumab } \\
45 \text { or } 90 \text { mg }\end{array}$ & 108weeks \\
\hline & $\begin{array}{l}\text { Mclnnes IB } \\
2015\end{array}$ & 397 & 48.0 & 48.4 & $\begin{array}{l}\text { Phase 3, randomized, } \\
\text { parallel assignment, } \\
\text { double-blind, placebo- } \\
\text { controlled study }\end{array}$ & $\begin{array}{l}\text { Placebo; } \\
\text { Secukinumab } \\
75,150 \text { or } \\
300 \mathrm{mg}\end{array}$ & 52weeks \\
\hline & $\begin{array}{l}\text { Mease PJ } \\
2015\end{array}$ & 606 & 49.0 & 54.5 & $\begin{array}{l}\text { Phase 3, randomized, } \\
\text { parallel assignment, } \\
\text { double-blind, placebo- } \\
\text { controlled study }\end{array}$ & $\begin{array}{l}\text { Placebo; } \\
\text { Secukinumab } \\
75 \text { or } 150 \text { mg }\end{array}$ & 24weeks \\
\hline & $\begin{array}{l}\text { Mease PJ } \\
2017\end{array}$ & 417 & 49.5 & 54.0 & $\begin{array}{l}\text { Phase } 3 \text {, randomized, } \\
\text { parallel assignment, } \\
\text { double-blind, placebo- } \\
\text { controlled study }\end{array}$ & $\begin{array}{l}\text { Placebo; } \\
\text { Ixekizumab }\end{array}$ & 24weeks \\
\hline
\end{tabular}




\begin{tabular}{|c|c|c|c|c|c|c|c|}
\hline Disease & Author & $\begin{array}{l}\text { Patients, } \\
\text { n }\end{array}$ & $\begin{array}{l}\text { Mean } \\
\text { age } \\
, y\end{array}$ & $\begin{array}{l}\text { Female } \\
\%\end{array}$ & Study design & Exposure & $\begin{array}{l}\text { Study } \\
\text { Duratiom }\end{array}$ \\
\hline & Nash P 2017 & 363 & 51.9 & 53.4 & $\begin{array}{l}\text { Phase 3, randomized, } \\
\text { parallel assignment, } \\
\text { double-blind, placebo- } \\
\text { controlled study }\end{array}$ & $\begin{array}{l}\text { Placebo; } \\
\text { Ixekizumab } \\
80 \text { mg }\end{array}$ & 24weeks \\
\hline & Nash P 2018 & 414 & 49.8 & 54.8 & $\begin{array}{l}\text { Phase 3, randomized, } \\
\text { parallel assignment, } \\
\text { double-blind, placebo- } \\
\text { controlled study }\end{array}$ & $\begin{array}{l}\text { Placebo; } \\
\text { Secukinumab } \\
150 \text { or } \\
300 \text { mg }\end{array}$ & 24weeks \\
\hline & Novartis 2015 & 42 & 47.0 & 64.3 & $\begin{array}{l}\text { Phase 2, randomized, } \\
\text { parallel assignment, } \\
\text { double-blind, placebo- } \\
\text { controlled study }\end{array}$ & $\begin{array}{l}\text { Placebo; } \\
\text { Secukinumab }\end{array}$ & 3weeks \\
\hline & $\begin{array}{l}\text { Van Der } \\
\text { Heijde D } 2019\end{array}$ & 997 & 48.8 & 49.8 & $\begin{array}{l}\text { Phase 3, randomized, } \\
\text { parallel assignment, } \\
\text { double-blind, placebo- } \\
\text { controlled study }\end{array}$ & $\begin{array}{l}\text { Placebo; } \\
\text { Secukinumab } \\
150 \text { or } \\
300 \text { mg }\end{array}$ & 24 weeks \\
\hline \multicolumn{8}{|c|}{ Ankylosing Spondylitis } \\
\hline & $\begin{array}{l}\text { Baeten D } \\
2015\end{array}$ & 371 & 41.8 & 30.7 & $\begin{array}{l}\text { Phase 3, randomized, } \\
\text { parallel assignment } \\
\text { double-blind, placebo- } \\
\text { controlled study }\end{array}$ & $\begin{array}{l}\text { Placebo; } \\
\text { Secukinumab }\end{array}$ & 16weeks \\
\hline & $\begin{array}{l}\text { Baeten D } \\
2015\end{array}$ & 219 & 43.3 & 30.1 & $\begin{array}{l}\text { Phase 3, randomized, } \\
\text { parallel assignment, } \\
\text { double-blind, placebo- } \\
\text { controlled study }\end{array}$ & $\begin{array}{l}\text { Placebo; } \\
\text { Secukinumab } \\
75 \text { or } 150 \mathrm{mg}\end{array}$ & 16weeks \\
\hline & $\begin{array}{l}\text { Pavelka K } \\
2017\end{array}$ & 226 & 42.5 & 39.8 & $\begin{array}{l}\text { Phase 3, randomized, } \\
\text { parallel assignment, } \\
\text { double-blind, placebo- } \\
\text { controlled study }\end{array}$ & $\begin{array}{l}\text { Placebo; } \\
\text { Secukinumab } \\
150 \text { or } \\
300 \text { mg }\end{array}$ & 16weeks \\
\hline & Kivitz AJ 2019 & 463 & 43.0 & 31.4 & $\begin{array}{l}\text { Phase 3, randomized, } \\
\text { parallel assignment, } \\
\text { double-blind, placebo- } \\
\text { controlled study }\end{array}$ & $\begin{array}{l}\text { Placebo; } \\
\text { Secukinumab } \\
150 \text { mg }\end{array}$ & 16weeks \\
\hline \multicolumn{8}{|c|}{ Rheumatoid arthritis } \\
\hline & $\begin{array}{l}\text { Blanco FJ } \\
2017\end{array}$ & 551 & 54.5 & 81.7 & $\begin{array}{l}\text { Phase 3, randomized, } \\
\text { parallel assignment, } \\
\text { double-blind, placebo- } \\
\text { controlled study }\end{array}$ & $\begin{array}{l}\text { Placebo; } \\
\text { Secukinumab }\end{array}$ & 24weeks \\
\hline & $\begin{array}{l}\text { Tlustochowicz } \\
\text { W } 2016\end{array}$ & 221 & 54.0 & 79.6 & $\begin{array}{l}\text { Phase 2, randomized, } \\
\text { parallel assignment, } \\
\text { double-blind, placebo- } \\
\text { controlled study }\end{array}$ & $\begin{array}{l}\text { Placebo; } \\
\text { Secukinumab }\end{array}$ & 16weeks \\
\hline & Tahir H 2017 & 637 & 52.9 & 87.3 & $\begin{array}{l}\text { Phase 3, randomized, } \\
\text { parallel assignment, } \\
\text { double-blind, placebo- } \\
\text { controlled study }\end{array}$ & $\begin{array}{l}\text { Placebo; } \\
\text { Secukinumab }\end{array}$ & 16weeks \\
\hline
\end{tabular}




\begin{tabular}{|c|c|c|c|c|c|c|c|}
\hline Disease & Author & $\begin{array}{l}\text { Patients, } \\
\text { n }\end{array}$ & $\begin{array}{l}\text { Mean } \\
\text { age } \\
, y\end{array}$ & $\begin{array}{l}\text { Female } \\
\%\end{array}$ & Study design & Exposure & $\begin{array}{l}\text { Study } \\
\text { Duratiom }\end{array}$ \\
\hline & $\begin{array}{l}\text { Smolen JS } \\
2017\end{array}$ & 274 & 51.5 & 83.2 & $\begin{array}{l}\text { Phase 2, randomized, } \\
\text { parallel assignment, } \\
\text { double-blind, placebo- } \\
\text { controlled study }\end{array}$ & $\begin{array}{l}\text { Placebo; } \\
\text { Ustekinumab } \\
90 \text { mg }\end{array}$ & 48weeks \\
\hline & $\begin{array}{l}\text { Dokoupilova E } \\
2018\end{array}$ & 242 & 54.2 & 83.5 & \multicolumn{2}{|c|}{$\begin{array}{l}\text { Phase 3, randomized, } \\
\text { parallel assignment, double-blind, } \\
\text { placebo-controlled study }\end{array}$} & 24weeks \\
\hline
\end{tabular}

The Cochrane manual recommends authors Cochrane risk bias assessment tools, which believes that bias can better reflect the quality of an RCT. All RCTs show low risk. The quality of evidence was high for every outcome.

All RCTs reported AEs and SAEs. Compared with placebo group, drug group obtained higher rate of AEs (64.2\% VS 49.5\%). Figure 1 shows the forest plot representing the pooled analysis of all studies on SAEs: The IL-23/17 axis antagonists treatment had significant effect on SAEs when analyzing the total population $[R R=1.95(1.55,2.44)]$. As for heterogeneity, $I^{2} \leq 50 \%$ is acceptable based on the Cochrane Book $\left(I^{2}=22 \%\right.$ and $\left.p=0.12\right)$.

Nervous system disorders were assessed in all studies, which included 13368 patients exposed to IL-23/17 axis antagonists. Overall, 8.3\% (1109) patients suffered nervous system disorders in drug group, which was higher than placebo-control group (5.2\%). Figure 2 shows the forest plot representing the pooled analysis of all studies on nervous system disorders: The IL-23/17 axis antagonists treatment had significant effect on nervous system disorder when analyzing the total population $[R R=1.56(1.32,1.84)]$. As for heterogeneity, $I^{2} \leq 50 \%$ is acceptable based on the Cochrane $\operatorname{Book}\left(I^{2}=14 \%\right.$ and $\left.p=0 \cdot 42\right)$.

Cardiovascular disorders were assessed in 31 studies, which included 12648 patients on IL-23/17 axis antagonists exposure. The global incidence was $1.6 \%$, whereas the incidence of patients exposed to the placebo was $0.5 \%$. Figure 3 shows the forest plot representing the pooled analysis of 31 studies on Cardiovascular disorders: The IL-23/17 axis antagonists treatment had significant effect on Cardiovascular disorders when analyzing the total population [RR = $2.06(1.39,3.06]]$. There was no evidence of heterogeneity in the outcome of incidence rate of cardiovascular disorder $\left(I^{2}=0 \%\right.$ and $\left.p=0.94\right)$.

Hypertension was assessed in 26 studies, which included 8909 patients exposed to IL-23/17 axis antagonists. Among them, 461 (5.2\%) of 5324 patients had hypertension, whereas the incidence of patients exposed to the placebo was $2.5 \%$. Figure 4 shows the forest plot representing the pooled analysis of 26 studies on hypertension: The IL-23/17 axis antagonists treatment had significant effect on hypertension when analyzing the total population $[R R=1.97(1.50$, 2.57)].

\section{Discussion}

This analysis is the first to evaluate the safety of IL-23/17 axis antagonists (Ustekinumab, Secukinumab, Ixekizumab) in patients with four IMIDs: PSO, PsA, AS, and RA. Our study synthesized the incident rates of AEs, SAEs and interested AEs (nervous system disorders, cardiovascular disorder, hypertension) from 36 RCTs.

Benefiting from the newly-developed therapies on IMIDs, patients with IMIDs are now having more options for the treatment. IL-23/17 axis antagonists have shown significant efficacy in IMIDs, and were used more frequently worldwide. It was paramount to define the safety profile of the medication. Overall, AEs and SAEs obtained higher incident rate in antagonists group. However, most of AEs were mild, and few of them led to drug discontinuation. 
Incidence rates of AEs and SAEs were 95.4 per 100 person-years and 9.3 per 100 person-years (Supplementary Table 2). In contrast to JAK antagonists exposure, incidence rates of AEs and SAEs were 42.69 per 100 person-years and 9.98 per 100 person-years, according to Olivera et al[41]. IL-23/17 antagonists show advantage in reducing SAEs. SAEs include major adverse cardiovascular event, cancer and other events which could be enough to death. In this aspect, IL-23/17 antagonists are safer than JAK antagonists. However, the high incidence of AEs might directly affect patients' quality of life. Thus, a further study in relationship between prevalence of AEs and patients' quality of life will be carried out.

There were also higher proportions of patients with nervous system disorders in the antagonists groups than placebo group. Mean incidence rate of nervous system disorders is 12.3 per 100 person-years (Supplementary Table 2). The majority of nervous system disorders is headache, of which the incidence rate on Ustekinumab therapy (10.3 per 100 person-years) is lower than Secukinumab (12.4 per 100 person-years) and Ixekizumab (15.5 per 100 person-years). This difference could be due to the fact that both Secukinumab and Ixekizumab block IL-17A, whereas Ustekinumab targetsp40 subunit of IL-23. McGinley AM et al reported that IL-17A recruits IL-1 $\beta$-secreting myeloid cells mainly including Y $\delta T 17$ and Th17 cells, both of which are prime pathogenic cells in central nervous system (CNS) autoimmunity [42]. Nevertheless, exact immunopathogenesis of high prevalence of nervous system disorders in patients with IMIDs exposure to IL23/17 antagonists are needed to explore.

Cardiovascular disorders were considered to be one of the biggest killers leading to death around the worldwide. Mean incidence rate of Cardiovascular disorders is 5.7 per 100 person-years (Supplementary Table 2).As the forest plot shows, more patients on antagonists therapy sustained cardiovascular disorders. Interestingly, the incidence rate of hypertension also increased in patients on IL23/17 antagonists therapy. Though, the exact pathogenic mechanism of the higher incidence rate of hypertension on IL23/17 antagonists therapy was not reported, it must be associated with the inflammatory cytokines and immune response on IL23/17 axis pathway. Anton Gisterå et al proved that IL-17dependent pathway promotes stabilization of atherosclerotic plaques [43]. Konstantinos Savvatis et al proved that IL23 play a key role in prognosis of myocardial infarction [44]. It accounts for patients undergoing therapeutic IL23/17 antagonists with higher incidence rate of cardiovascular disorder.

There are several limitations in our study. First, present study only focused on the most commonly used IL-23/17 axis antagonists such as Ustekinumab, Secukinumab and Ixekizumab, therefore other medications involved in IL-23/17 axis inhabitation need to be further studied. Secondly, most of the included studies were conducted in PSO, followed by PsA, and the number of studies regarding to AS and RA was limited. Thirdly, this analysis only included placebo-controlled RCTs to assure the quality of the evidence. It may influence the rate of AEs in total. Fourthly, the patient eligible for analysis are 18 years old or older, not including juveniles. Additionally, regard as the absence of enough data from longterm studies

In conclusion, the results of present analysis support that the use of IL-23/17 antagonists for the treatment of PSO, PsA, AS and RA increased the incidence rates of AEs, SAEs and interest of AEs (nervous system disorders, cardiovascular disorder, hypertension). To fully evaluate the safety profile of the different IL-23/17 antagonists, there need to be more long-term studies.

\section{Declarations}

\section{Ethics approval and consent to participate}

Not applicable. 


\section{Consent for publication}

Not applicable.

\section{Availability of data and materials}

Not applicable.

\section{Competing interests}

The authors declare that they have no competing interests.

\section{Funding}

This work was supported by the National Natural Science Foundation of China 81573051 and 81872534 ) to Y.Su

\section{Funding sources}

National Natural Science Foundation of China (81573051 and 81872534) to Yuwen Su.

\section{Conflicts of Interest}

The authors have declared that no conflict of interest exists.

\section{Authors' contributions}

All authors were involved in this meta-analysis. SL designed the study and was a major contributor in this work. All authors collected data from studies conformed to selection criteria. All authors read and approved the final manuscript.

\section{Acknowledgements}

Not applicable.

\section{References}

1. Parisi R, Symmons DP, Griffiths CE, Ashcroft DM. Global epidemiology of psoriasis: a systematic review of incidence and prevalence. J Invest Dermatol. 2013;133(2):377-85. doi:10.1038/jid.2012.339[published Online First: Epub Date]|.

2. Rachakonda TD, Schupp CW, Armstrong AW. Psoriasis prevalence among adults in the United States. J Am Acad Dermatol. 2014;70(3):512-6. doi:10.1016/j.jaad.2013.11.013[published Online First: Epub Date]|.

3. Christophers E. Psoriasis-epidemiology and clinical spectrum. Clin Exp Dermatol. 2001;26(4):314-20. doi:10.1046/j.1365-2230.2001.00832.x[published Online First: Epub Date]|. 
4. Boehncke WH, Schön MP. Psoriasis Lancet. 2015;386(9997):983-94. i: 10.1016/s0140-6736(14)61909-

7[published Online First: Epub Date]|. ; ): do.

5. Rendon A, Schäkel K. Psoriasis Pathogenesis and Treatment. Int J Mol Sci 2019;20(6) doi: 10.3390/ijms20061475[published Online First: Epub Date]|..

6. Bridgewood C, Sharif K, Sherlock J, Watad A, McGonagle D. Interleukin-23 pathway at the enthesis: The emerging story of enthesitis in spondyloarthropathy. Immunol Rev. 2020;294(1):27-47. doi:10.1111/imr.12840[published Online First: Epub Date]|.

7. Di Cesare A, Di Meglio P, Nestle FO. The IL-23/Th17 axis in the immunopathogenesis of psoriasis. J Invest Dermatol. 2009;129(6):1339-50. doi:10.1038/jid.2009.59[published Online First: Epub Date]|.

8. Higgins JPT, Altman DG, Gøtzsche PC, et al. The Cochrane Collaboration's tool for assessing risk of bias in randomised trials. BMJ. 2011;343:d5928-28. doi:10.1136/bmj.d5928[published Online First: Epub Date]|.

9. Krueger GG, Langley RG, Leonardi C, et al. A human interleukin-12/23 monoclonal antibody for the treatment of psoriasis. N Engl J Med. 2007;356(6):580-92. i: 10.1056/NEJMoa062382[published Online First: Epub Date]|.. (: do.

10. Leonardi CL, Kimball AB, Papp KA, et al. Efficacy and safety of Ustekinumab, a human interleukin-12/23 monoclonal antibody, in patients with psoriasis: 76-week results from a randomised, double-blind, placebocontrolled trial (PHOENIX 1). Lancet. 2008;371(9625):1665-74. doi:10.1016/s0140-6736(08)60725-4[published Online First: Epub Date]|.

11. Papp KA, Langley RG, Lebwohl M, et al. Efficacy and safety of Ustekinumab, a human interleukin-12/23 monoclonal antibody, in patients with psoriasis: 52-week results from a randomised, double-blind, placebocontrolled trial (PHOENIX 2). Lancet. 2008;371(9625):1675-84. doi:10.1016/s0140-6736(08)60726-6[published Online First: Epub Date]|.

12. Gottlieb A, Menter A, Mendelsohn A, et al. Ustekinumab, a human interleukin 12/23 monoclonal antibody, for psoriatic arthritis: randomised, double-blind, placebo-controlled, crossover trial. Lancet. 2009;373(9664):633-40. i: 10.1016/s0140-6736(09)60140-9[published Online First: Epub Date]|. ( : do.

13. Novartis-NCT01071252. Randomized A. Double-blind, Placebo Controlled, Multicenter Dose Ranging Study of Subcutaneously Administered AIN457, Assessing Psoriasis Area and Severity Index (PASI) Response in Patients With Moderate to Severe Chronic Plaque-type Psoriasis. 2010.

14. Novartis-NCT01555125. 2012.

15. Leonardi C, Matheson R, Zachariae C, et al. Anti-interleukin-17 monoclonal antibody Ixekizumab in chronic plaque psoriasis. N Engl J Med. 2012;366(13):1190-9. i: 10.1056/NEJMoa1109997[published Online First: Epub Date]|.. (: do.

16. Genovese MC, Durez P, Richards HB, et al. Efficacy and safety of Secukinumab in patients with rheumatoid arthritis: a phase II, dose-finding, double-blind, randomised, placebo controlled study. Ann Rheum Dis. 2013;72(6):863-9. doi:10.1136/annrheumdis-2012-201601[published Online First: Epub Date]|.

17. McInnes IB, Kavanaugh A, Gottlieb AB, et al. Efficacy and safety of Ustekinumab in patients with active psoriatic arthritis: 1 year results of the phase 3, multicentre, double-blind, placebo-controlled PSUMMIT 1 trial. Lancet. 2013;382(9894):780-9. doi:10.1016/s0140-6736(13)60594-2[published Online First: Epub Date]|.

18. Langley RG, Elewski BE, Lebwohl M, et al. Secukinumab in plaque psoriasis-results of two phase 3 trials. N Engl J Med. 2014;371(4):326-38. i: 10.1056/NEJMoa1314258[published Online First: Epub Date]|.. ( : do.

19. Baeten D, Sieper J, Braun J, et al. Secukinumab, an Interleukin-17A Inhibitor, in Ankylosing Spondylitis. N Engl J Med. 2015;373(26):2534-48. i: 10.1056/NEJMoa1505066[published Online First: Epub Date]|.. ( : do. 
20. McInnes IB, Mease PJ, Kirkham B, et al. Secukinumab, a human anti-interleukin-17A monoclonal antibody, in patients with psoriatic arthritis (FUTURE 2): a randomised, double-blind, placebo-controlled, phase 3 trial. Lancet. 2015;386(9999):1137-46. doi:10.1016/s0140-6736(15)61134-5[published Online First: Epub Date]|.

21. Mease PJ, Mclnnes IB, Kirkham B, et al. Secukinumab Inhibition of Interleukin-17A in Patients with Psoriatic Arthritis. N Engl J Med. 2015;373(14):1329-39. i: 10.1056/NEJMoa1412679[published Online First: Epub Date]|.. (: do.

22. Paul C, Lacour JP, Tedremets L, et al. Efficacy, safety and usability of Secukinumab administration by autoinjector/pen in psoriasis: a randomized, controlled trial (JUNCTURE). J Eur Acad Dermatol Venereol. 2015;29(6):1082-90. doi:10.1111/jdv.12751[published Online First: Epub Date]|.

23. Novartis-NCT00809614. https://clinicaltrials.gov/ct2/show/NCT00809614 2015.

24. Novartis-NCT00805480. Phase II Randomized, Double-blind, Multi-center, Parallel-group, Placebo-controlled Multiple-loading Dose Regimen Study to Assess the Safety, Efficacy and Duration of Response of AIN457 in Patients With Chronic Plaque-type Psoriasis. https://clinicaltrials.gov/ct2/show/NCT00805480 2015.

25. Gordon KB, Blauvelt A, Papp KA, et al. Phase 3 Trials of Ixekizumab in Moderate-to-Severe Plaque Psoriasis. N Engl J Med. 2016;375(4):345-56. i: 10.1056/NEJMoa1512711[published Online First: Epub Date]|.. ( : do.

26. Kavanaugh A, Puig L, Gottlieb AB, et al. Efficacy and safety of Ustekinumab in psoriatic arthritis patients with peripheral arthritis and physician-reported spondylitis: post-hoc analyses from two phase III, multicentre, doubleblind, placebo-controlled studies (PSUMMIT-1/PSUMMIT-2). Ann Rheum Dis. 2016;75(11):1984-88. i: 10.1136/annrheumdis-2015-209068[published Online First: Epub Date]|.. ( : do.

27. Tlustochowicz W, Rahman P, Seriolo B, et al. Efficacy and Safety of Subcutaneous and Intravenous Loading Dose Regimens of Secukinumab in Patients with Active Rheumatoid Arthritis: Results from a Randomized Phase II Study. J Rheumatol. 2016;43(3):495-503. i: 10.3899/jrheum.150117[published Online First: Epub Date]|.. ( : do.

28. Randomized Novartis-NCT03066609A, Controlled DP. Multicenter Study of Subcutaneous Secukinumab, to Demonstrate Efficacy After Twelve Weeks of Treatment and to Assess Safety, Tolerability and Long-term Efficacy up to One Year in Subjects With Moderate to Severe Chronic Plaque-type Psoriasis With or Without Psoriatic Arthritis Comorbidity. 2017.

29. Mease PJ, van der Heijde D, Ritchlin CT, et al. Ixekizumab, an interleukin-17A specific monoclonal antibody, for the treatment of biologic-naive patients with active psoriatic arthritis: results from the 24-week randomised, doubleblind, placebo-controlled and active (adalimumab)-controlled period of the phase III trial SPIRIT-P1. Ann Rheum Dis. 2017;76(1):79-87. i: 10.1136/annrheumdis-2016-209709[published Online First: Epub Date]|.. (: do.

30. Pavelka K, Kivitz A, Dokoupilova E, et al. Efficacy, safety, and tolerability of Secukinumab in patients with active ankylosing spondylitis: a randomized, double-blind phase 3 study, MEASURE 3. Arthritis Res Ther. 2017;19(1):285. doi:10.1186/s13075-017-1490-y[published Online First: Epub Date]|.

31. Blanco FJ, Moricke R, Dokoupilova E, et al. Secukinumab in Active Rheumatoid Arthritis: A Phase III Randomized, Double-Blind, Active Comparator- and Placebo-Controlled Study. Arthritis Rheumatol. 2017;69(6):1144-53. doi:10.1002/art.40070[published Online First: Epub Date]|.

32. Smolen JS, Agarwal SK, llivanova E, et al. A randomised phase II study evaluating the efficacy and safety of subcutaneously administered Ustekinumab and guselkumab in patients with active rheumatoid arthritis despite treatment with methotrexate. Ann Rheum Dis. 2017;76(5):831-39. i: 10.1136/annrheumdis-2016209831[published Online First: Epub Date]|.. ( : do.

33. Tahir H, Deodhar A, Genovese M, et al. Secukinumab in Active Rheumatoid Arthritis after Anti-TNFalpha Therapy: A Randomized, Double-Blind Placebo-Controlled Phase 3 Study. Rheumatol Ther. 2017;4(2):475-88. doi:10.1007/s40744-017-0086-y[published Online First: Epub Date]|. 
34. Nash P, Kirkham B, Okada M, et al. Ixekizumab for the treatment of patients with active psoriatic arthritis and an inadequate response to tumour necrosis factor inhibitors: results from the 24-week randomised, double-blind, placebo-controlled period of the SPIRIT-P2 phase 3 trial. Lancet. 2017;389(10086):2317-27. doi:10.1016/s01406736(17)31429-0[published Online First: Epub Date]|.

35. Nash P, Mease PJ, McInnes IB, et al. Efficacy and safety of Secukinumab administration by autoinjector in patients with psoriatic arthritis: results from a randomized, placebo-controlled trial (FUTURE 3). Arthritis Res Ther. 2018;20(1):47. doi:10.1186/s13075-018-1551-x[published Online First: Epub Date]|.

36. Dokoupilova E, Aelion J, Takeuchi T, et al. Secukinumab after anti-tumour necrosis factor-alpha therapy: a phase III study in active rheumatoid arthritis. Scand J Rheumatol. 2018;47(4):276-81 doi. 5[published Online First: Epub Date]|.. ( :: 10.1080/03009742.2017.139060.

37. van der Heijde D, Mease PJ, Landewé RBM, et al. Secukinumab provides sustained low rates of radiographic progression in psoriatic arthritis: 52-week results from a phase 3 study, FUTURE 5. Rheumatology. 2019. doi:10.1093/rheumatology/kez420[published Online First: Epub Date]|.

38. Huang Y, Fan Y, Liu Y, Xie W, Zhang Z. Efficacy and safety of Secukinumab in active rheumatoid arthritis with an inadequate response to tumor necrosis factor inhibitors: a meta-analysis of phase III randomized controlled trials. Clin Rheumatol. 2019;38(10):2765-76. doi:10.1007/s10067-019-04595-1[published Online First: Epub Date]|.

39. Kivitz AJ, Nash P, Tahir H, et al. Efficacy and Safety of Subcutaneous Secukinumab 150 mg with or Without Loading Regimen in Psoriatic Arthritis: Results from the FUTURE 4 Study. Rheumatol Ther. 2019;6(3):393-407 doi. 5[published Online First: Epub Date]|.. ( :: 10.1007/s40744-019-0163-.

40. Deodhar A, Gladman DD, McInnes IB, et al. Secukinumab Immunogenicity over 52 Weeks in Patients with Psoriatic Arthritis and Ankylosing Spondylitis. J Rheumatol. 2020;47(4):539-47. i: 10.3899/jrheum.190116[published Online First: Epub Date]|.. ( : do.

41. Olivera PA, Lasa JS, Bonovas S, Danese S, Peyrin-Biroulet L. Safety of Janus Kinase Inhibitors in Patients With Inflammatory Bowel Diseases or Other Immune-mediated Diseases: A Systematic Review and Meta-Analysis. Gastroenterology. 2020;158(6):1554-73.e12. doi:10.1053/j.gastro.2020.01.001[published Online First: Epub Date]|.

42. McGinley AM, Sutton CE, Edwards SC, et al. Interleukin-17A Serves a Priming Role in Autoimmunity by Recruiting IL1 beta-Producing Myeloid Cells that Promote Pathogenic T Cells. Immunity 2020;52(2):342 - 56.e6 doi: 10.1016/j.immuni.2020.01.002[published Online First: Epub Date]|.

43. Gisterå A, Robertson AK, Andersson J, et al. Transforming growth factor- $\beta$ signaling in $T$ cells promotes stabilization of atherosclerotic plaques through an interleukin-17-dependent pathway. Sci Transl Med. 2013;5(196):196ra00. doi:10.1126/scitransImed.3006133[published Online First: Epub Date]|.

44. Savvatis K, Pappritz K, Becher PM, et al. Interleukin-23 deficiency leads to impaired wound healing and adverse prognosis after myocardial infarction. Circ Heart Fail. 2014;7(1):161-71.

doi:10.1161/circheartfailure.113.000604[published Online First: Epub Date]|.

\section{Figures}




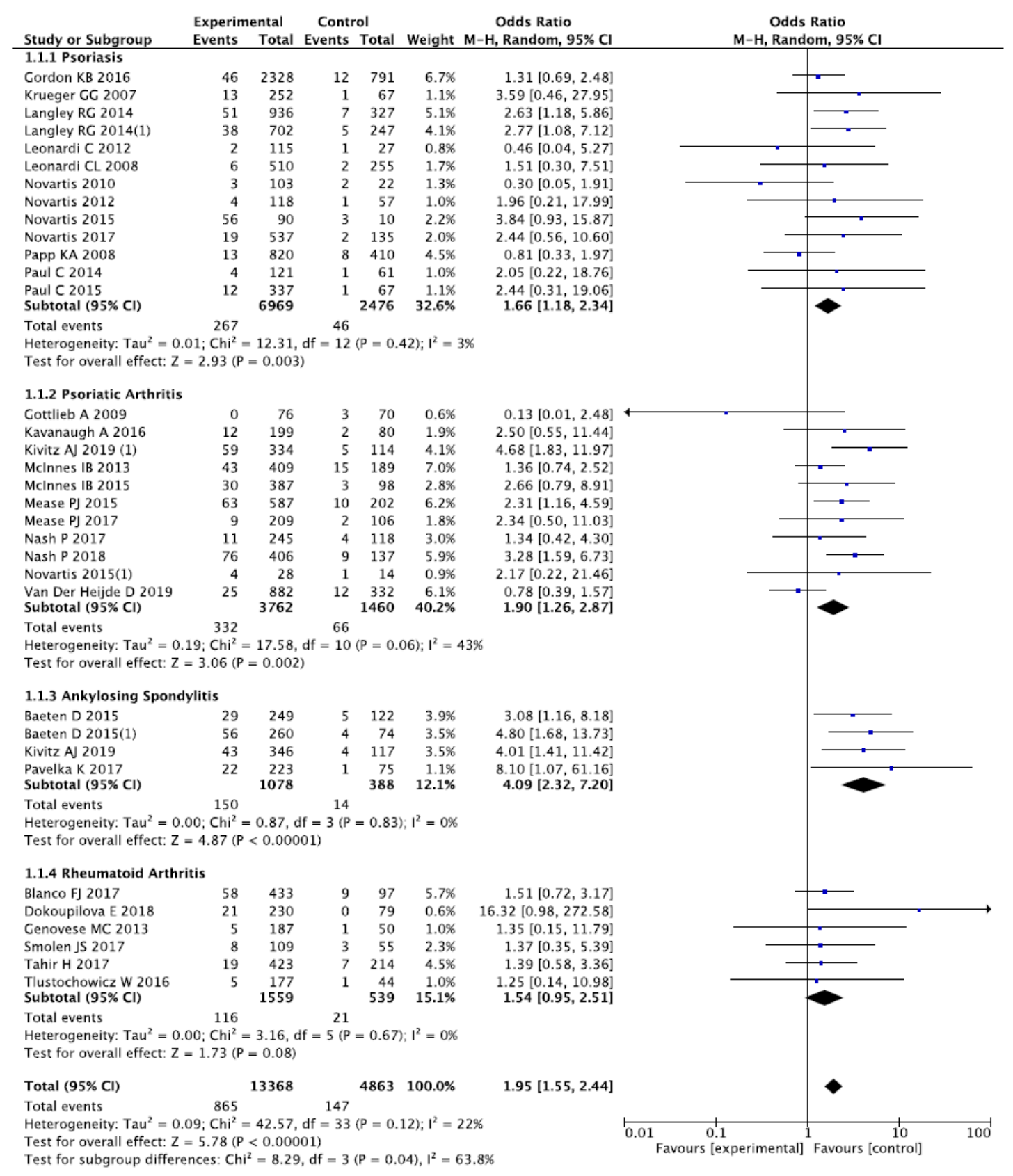

\section{Figure 1}

Forest plot comparing the incidence rate of serious adverse events for IL-23/17 axis antagonists group versus placebocontrolled group. 
Experimental Control

Odds Ratio

Odds Ratio

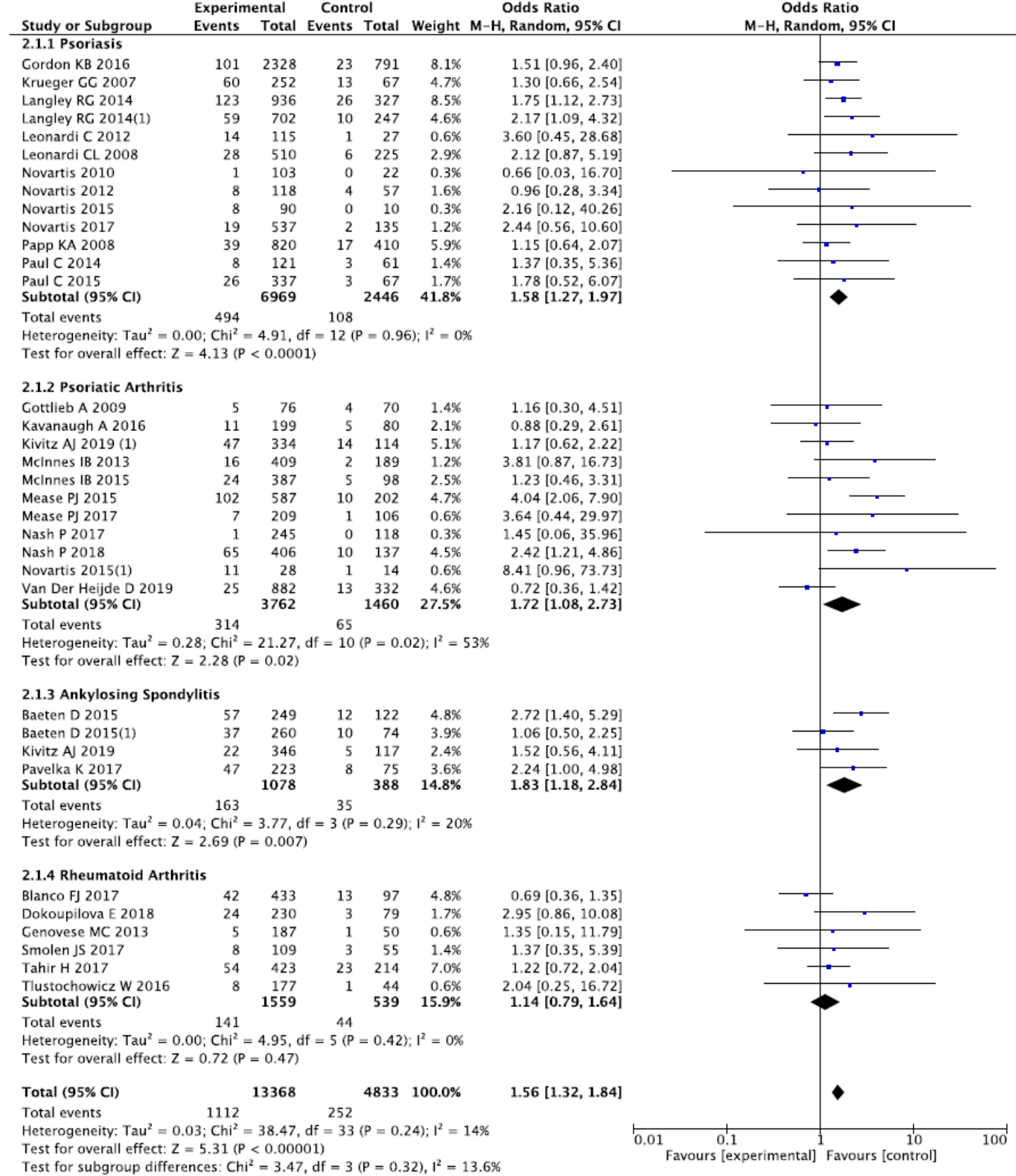

\section{Figure 2}

Forest plot comparing the incidence rate of nervous system disorders for IL-23/17 axis antagonists group versus placebo-controlled group. 


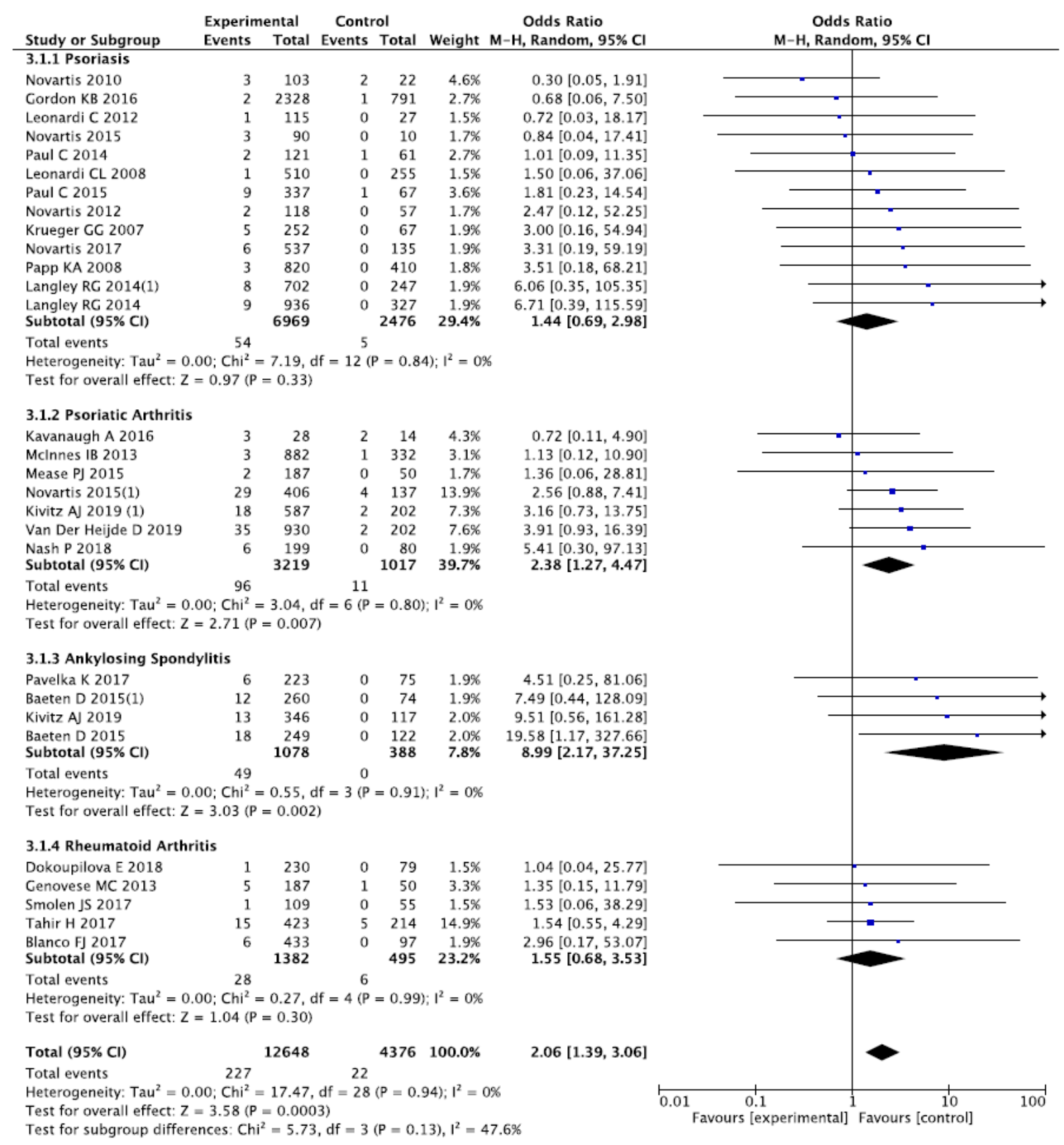

\section{Figure 3}

Forest plot comparing the incidence rate of cardiovascular disorders for IL-23/17 axis antagonists group versus placebo-controlled group. 
Experimental Control Odds Ratio

Events Total Events Total Weight $\mathrm{M}-\mathrm{H}, \mathrm{Random}, 95 \% \mathrm{Cl}$

Study or Subgroup

Events Total Events Total Weight $M-H$, Random, $95 \% \mathrm{Cl}$

4.1.1 Psoriasis

Langley RG 2014

Langley RG 2014(1)

$\begin{array}{lllll}42 & 936 & 4 & 327 & 6.4 \% \\ 36 & 702 & 3 & 247 & 4.9 \%\end{array}$

$3.79[1.35,10.66]$

Leonardi C 2012

$4.40[1.34,14.41]$

$0.70[0.07,6.97]$

$1.13[0.34,3.70]$

Leonardi CL 2008

$\begin{array}{lllll}9 & 510 & 4 & 255 & 4.9 \%\end{array}$

Novartis 2010

Novartis 2012

103

$\begin{array}{lll}0 & 22 & 0.8 \% \\ 1 & 57 & 1.4 \%\end{array}$

$2.04[0.11,39.17]$

$1.46[0.15,14.36]$

$2.45[0.13,45.18]$

$1.73[0.60,5.04]$

$0.49[0.12,2.02]$

$1.02[0.12,8.61]$

$1.80[1.11,2.91]$

Paul C 2015

Subtotal $(95 \% \mathrm{Cl})$

$4 \quad 135 \quad 6.0 \%$

$461 \quad 3.4 \%$

$\begin{array}{llll}394 & 1 & 67 & 1.6 \%\end{array}$

Total events

143

$1208 \quad 31.4 \%$

Heterogeneity: $\mathrm{Tau}^{2}=0.02 ; \mathrm{Chi}^{2}=9.34, \mathrm{df}=9(\mathrm{P}=0.41) ; \mathrm{I}^{2}=4 \%$

Test for overall effect: $Z=2.38(P=0.02)$

4.1.2 Psoriatic Arthritis

$\begin{array}{lrrrrr}\text { Kivitz AJ 2019 (1) } & 32 & 334 & 4 & 114 & 6.0 \% \\ \text { McInnes IB 2013 } & 32 & 409 & 9 & 189 & 11.3 \% \\ \text { Mease PJ 2015 } & 39 & 587 & 5 & 202 & 7.5 \% \\ \text { Nash P 2018 } & 28 & 406 & 3 & 137 & 4.7 \% \\ \text { Novartis 2015(1) } & 2 & 28 & 0 & 14 & 0.7 \% \\ \text { Van Der Heijde D 2019 } & 22 & 882 & 10 & 332 & 11.3 \% \\ \text { Subtotal (95\% CI) } & & 2646 & & 988 & 41.6 \% \\ \text { Total events } & 155 & & 31 & & \end{array}$

$2.91[1.01,8.43]$

$1.70[0.79,3.63]$

$2.80[1.09,7.22]$

$3.31[0.99,11.06]$

$2.74[0.12,60.92]$

$0.82[0.39,1.76]$

$1.87[1.15,3.06]$

$\begin{array}{lcc}\text { Total events } & 155 & 31 \\ \text { Heterogeneity: } \mathrm{Tau}^{2}=0.10 ; \mathrm{Chi}^{2}=6.91, \mathrm{df}=5(\mathrm{P}=0.23) ; \mathrm{I}^{2}=28 \%\end{array}$

Test for overall effect: $Z=2.50(P=0.01)$

4.1.3 Ankylosing Spondylitis

$\begin{array}{lrrrrrr}\text { Baeten D 2015 } & 10 & 249 & 0 & 122 & 0.9 \% & 10.74[0.62,184.83] \\ \text { Baeten D 2015(1) } & 24 & 260 & 0 & 74 & 0.9 \% & 15.44[0.93,256.90] \\ \text { Kivitz AJ 2019 } & 18 & 346 & 2 & 117 & 3.2 \% & 3.16[0.72,13.81] \\ \text { Pavelka K 2017 } & 12 & 223 & 0 & 75 & 0.9 \% & 8.92[0.52,152.58] \\ \text { Subtotal (95\% CI) } & & \mathbf{1 0 7 8} & & \mathbf{3 8 8} & \mathbf{5 . 8 \%} & \mathbf{5 . 6 2}[\mathbf{1 . 8 8}, \mathbf{1 6 . 8 2}]\end{array}$

Total events 64

Heterogeneity: $\mathrm{Tau}^{2}=0.00 ; \mathrm{Chi}^{2}=1.49, \mathrm{df}=3(\mathrm{P}=0.68) ; \mathrm{I}^{2}=0 \%$

Test for overall effect: $Z=3.09(P=0.002)$

4.1.4 Rheumatoid Arthritis

Dokoupilova E 2018

Genovese MC 2013

Smolen JS 2017

Tahir H 2017

Tlustochowicz W 2016

Subtotal $(95 \% \mathrm{CI})$

Total events

$38 \quad 433$

$11 \quad 230$

1187

$7 \quad 109$

$\begin{array}{lllll}30 & 423 & 5 & 214 & 7.3 \%\end{array}$

$\begin{array}{rrrrr}3 & 177 & 1 & 44 & 1.4 \% \\ & 1559 & & 539 & 21.1 \%\end{array}$

90 14

Heterogeneity: $\mathrm{Tau}^{2}=0.00 ; \mathrm{Chi}^{2}=3.60, \mathrm{df}=5(\mathrm{P}=0.61) ; \mathrm{I}^{2}=0 \%$

Test for overall effect: $Z=2.40(P=0.02)$

Total $(95 \% \mathrm{Cl})$

8909

Total events 452

$3123100.0 \%$

Heterogeneity: $\mathrm{Tau}^{2}=0.01 ; \mathrm{Chi}^{2}=25.75, \mathrm{df}=25(\mathrm{P}=0.42) ; \mathrm{I}^{2}=3 \%$

Test for overall effect: $Z=4.96(P<0.00001)$

Test for subgroup differences: $\mathrm{Chi}^{2}=3.67, \mathrm{df}=3(\mathrm{P}=0.30), \mathrm{I}^{2}=18.3 \%$
$\mathrm{M}-\mathrm{H}$, Random, $95 \% \mathrm{Cl}$

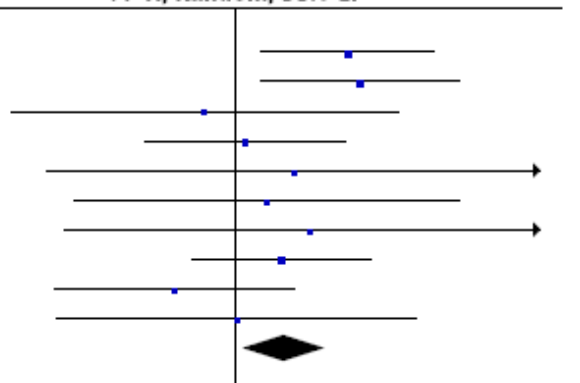

$1.77[0.68,4.62]$

$8.33[0.49,143.01]$

$0.81[0.03,20.24]$

$1.19[0.30,4.79]$

$3.19[1.22,8.35]$

$0.74[0.08,7.30]$

$2.00[1.13,3.54]$

$1.97[1.50,2.57]$

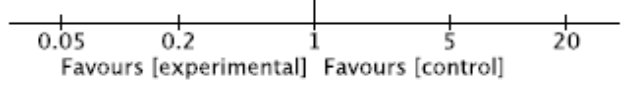

\section{Figure 4}

Forest plot comparing the incidence rate of hypertension for IL-23/17 axis antagonists group versus placebo-controlled group.

\section{Supplementary Files}

This is a list of supplementary files associated with this preprint. Click to download.

- SupplementaryFigure1.doc

- SupplementalTable1.docx

- SupplementalTable2.docx 